relics of this first-known fish have hitherto been found. Some excavations, made of late in the passage beds between the old red sandstone and the Ludlow rocks at Ledbury in Herefordshire, have afforded a fine series of the fish found in the 'bone-bed' and passage rocks. Among them, Mr. Piper has obtained plates and cephalic shields of Scaphaspis, Pteraspis, Cyathaspis, and Auchenaspis. Auchenaspis has been found perfect; and much more of the structure of these early fishes has come to light. But there is a good deal of difference in the geological horizon of these fish at Ledbury and that of the Scaphaspis at Leintwardine. The lower Ludlows appear in great thickness at Ledbury, but hitherto they have not presented us with fish.

The Camp, Sunningdale, July 31.

\section{Depth of the glacial submergence on the upper Mississippi.}

I desire to call attention to certain facts which appear to me to indicate a submergence of even the highest land at this point, which, it may be said, is near the centre of the driftless area. I am not aware of their having been previously noted.

That which first called my attention to the matter was the discovery that the layer of broken stone which covers the undisturbed rock on the top of the bluffs to a depth of four to six feet, contained numerous shells belonging to several species of pulmoniferous gasteropods. I have thus far obtained specimens of the following species (the identifications were kindly furnished by Mr. Sanderson Smith of the U.S. fish-commission): Helicina acculeata Say, Lymneae columella Say, Helix (Patula) attenuata Say, Helix (Helicodiscus) lineata Say, Helix (Patula) striatella Anthony.

The condition of the shells, and the positions in which found, even more than the mere fact of their occurrrence, indicate submergence by giving strong evidence of wave-action, evidence of which is also seen in the general order and arrangement of the stones composing the layer, especially in the remarkable evenness of its upper surface. Overlying this layer of broken stone, and sharply distinguished from it, is a layer of earth from two to four feet thick, destitute of either stones or shells, and having all the characteristics of the loess, which, in unmistakable deposits, reaches a height of two to three hundred feet above the Mississippi. As the bluffs at this point reach to about five hundred feet above the river, a submergence to at least that extent is indicated, - a conclusion which is sustained by other facts, which I need not now refer to.

Trempealeau, Wis.

G. H. SQUIER.

\section{THE VISIT OW THE BRITISH ASSOCIA- TION.}

Although the British association does not meet officially on our own soil, we may yet regard it as in some sort paying a visit to our neighborhood, and opening up such an opportunity for personal communication between the scientific men of England and America as has never before offered itself. It is true that Principal Grant, as a Canadian by adoption, sug- gests to the members to be satisfied with Canada on this occasion, "and to leave the United States and Mexico to other and more convenient seasons." He strengthens this suggestion by the statement that the time of meeting of the American association was chosen so as to give the members of that body an opportunity of visiting Montreal, thus correcting the current impression that the object was to make it convenient for the members of the British association to visit Philadelphia. The Canadians may also feel fairly entitled to all the credit which the visit of the association can bring, since so long a journey by so large a body of men would hardly have been seriously considered, but for Canadian enterprise. A proposal was privately discussed among us, a few years ago, to invite the British association to Boston on the occasion of the anticipated exposition of 1883. But, after the exposition was abandoned, no one was so bold as to seriously press the invitation in the absence of any special attraction to second it; and it was left for our neighbors to successfully attack the problem which we had abandoned as hopeless. It is not, however, to be expected that the individual members of the association will be greatly influenced by sentiment in the use they make of their time on this side of the ocean, or that Canadian pride, enterprise, or loyalty, will prevent them from crossing the border. Not even such energy as that of our neighbors, and such glory as that of their dominion, can compensate for the charm of novelty in life and institutions offered the foreigner by such countries as "the United States and Mexico." It may be well worth the while of a studious Englishman to take a long journey to learn from actual inspection what an English province can become under the influence of so energetic a people as those of Canada; but he cannot suppress his curiosity to study the ampler and more varied civilization which his race is working out under political conditions less like those to which he is accustomed. We therefore look upon the present meeting as nearly the equivalent of a visit to our own country, and, in the name of the stu- 